\title{
Microbiological Laboratory Hazard of Bearded Men
}

\author{
MANUEL S. BARBEITO, CHARLES T. MATHEWS, AND LARRY A. TAYLOR \\ Industrial Health and Safety Office, Fort Detrick, Frederick, Maryland 21701
}

Received for publication 6 March 1967

\begin{abstract}
An investigation was conducted to evaluate the hypothesis that a bearded man subjects his family and friends to risk of infection if his beard is contaminated by infectious microorganisms while he is working in a microbiological laboratory. Bearded and unbearded men were tested with Serratia marcescens and Bacillus subtilis var. niger. Contact aerosol transmission from a contaminated beard on a mannequin to a suitable host was evaluated with both Newcastle disease virus and Clostridium botulinum toxin, type A. The experiments showed that beards retained microorganisms and toxin despite washing with soap and water. Although washing reduced the amount of virus or toxin, a sufficient amount remained to produce disease upon contact with a suitable host.
\end{abstract}

Indirect contact transmission of disease from the microbiological laboratory to persons outside by means of contaminated clothing has been reported in the instances of $\mathbf{Q}$ fever in laundry workers (11) and in a veterinarian's wife who may have acquired $Q$ fever by handling the clothing of her husband (6).

There may be other cases of similar indirect transmission. However, there are few reports of direct personal contact in which a healthy microbiological laboratory worker has infected his family or friends outside the laboratory. One paper reported the $\mathbf{Q}$ fever infection of a housewife by a tenant in her home; it was concluded that the most reasonable theory was passive carriage of the organism from the laboratory either on the clothing, hands, shoes, or hair (2).

After many years of absence from the laboratory scene, beards are now being worn by some persons working with pathogenic microorganisms. Beard contamination might result from an evident spill of culture or from an unrecognized microbial aerosol. Previous investigations have shown that common microbiological techniques and accidents generate sufficient microbial aerosol to infect man (22). It is assumed that differences in susceptibility may permit infection of a contact even if the bearded carrier remains uninfected. Because the source of laboratory-acquired infection is unknown in 39 to $86 \%$ of the cases (12), it has been our policy that beards are undesirable because they may constitute a risk to close associates.

This hypothesis was tested by four volunteers with 73-day-old beards. Noninfective Serratia marcescens and Bacillus subtilis var. niger were used in the test.

To study transmission of disease by a beard, a full-length, natural-hair beard on a mannequin was contaminated with Newcastle disease virus (NDV) and Clostridium botulinum type A toxin. Chickens and guinea pigs were used as test animals.

\section{Materials AND METHODS}

Bacterial experiments with bearded men. Two bacterial cultures were used in this investigation. $S$. marcescens was grown for $16 \mathrm{hr}$ at $30 \mathrm{C}$ in a modified Tryptose Broth medium (Difco) and was diluted with physiological saline immediately before use to a concentration of $10^{5}$ organisms $/ \mathrm{ml}$. B. subtilis var. niger was grown for $48 \mathrm{hr}$ at $34 \mathrm{C}$ in a modified $\mathrm{N}$-Z Amine Type A medium and was diluted with physiological saline immediately before use to a concentration of $10^{4}$ spores $/ \mathrm{ml}$.

A 1-ml amount of culture was sprayed from a small Chicago atomizer (17) on the entire beard of each man. In the final experiment in which one half the beard was sprayed before shearing off the beard, only $0.5 \mathrm{ml}$ was used. The particles had a mass median diameter of approximately 3 to $5 \mu$.

Two intervals, $30 \mathrm{~min}$ and $6 \mathrm{hr}$, were used between spraying and sampling the beard. The 30-min interval was selected to represent two work situations: (i) the time necessary for a man to complete a laboratory operation in a zealous attempt to avoid loss of an experimental series despite a known accidental contamination of his beard before he rejoined his associates with an unwashed beard, and (ii) the time required for an immediate shower and change of clothing, after an accident that contaminated the beard and the before association with fellow employees or family. The 6-hr interval was selected to represent the time between an unrecognized contamination of the beard and family contact with the unwashed beard.

The test site was an isolated laboratory room with both the temperature and humidity controlled. During 

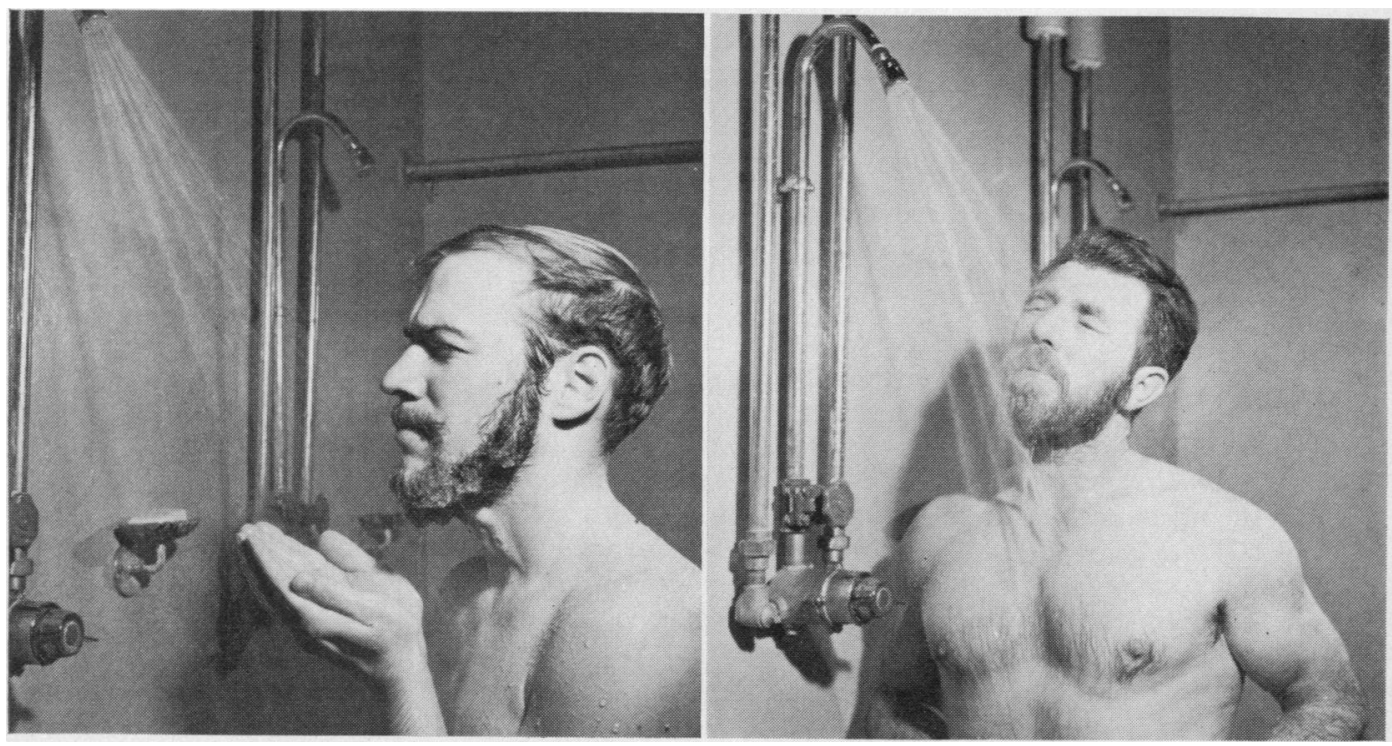

FIG. 1. Beard-washing methods. Left: splashing wash. Right: shower stream wash.

the 30-min interval between spraying and sampling of the beard, to dry the beard with maximal retention of bacterial viability, the temperature was controlled between 21 and $26 \mathrm{C}$ and the relative humidity was adjusted to a range of 70 to $75 \%$. Preliminary investigation revealed that a relative humidity of about $70 \%$ aided organism recovery. Webb (21) discussed in considerable detail the effect of relative humidity on the decay rate of several microorganisms, including those used in this investigation. Extrapolation from a graph by Webb showed that the death rate of cells after $1 \mathrm{hr}$ at $70 \%$ relative humidity and $25 \mathrm{C}$ was 0.005 for $B$. subtilis and 0.01 for $S$. marcescens. During the 6-hr interval, temperature and humidity were not controlled; the bearded subjects went about their usual business without doing any microbiological work.

After the drying period, each man lathered his beard with a soap containing $2 \%$ hexachlorophene (3) and then rinsed it by one of two beard-washing methods: (i) a splashing method, by cupping the hands to catch the water and then splashing the water across the face; or (ii) a shower stream method, by placing the face directly under the stream of water from the shower head (Fig. 1). Each method was used by two volunteers. Then the beard was dried with a sterile towel.

Four sampling methods were used on each beard for bacterial recovery, plus a fifth when $S$. marcescens was the test organism. (i) Each beard was swabbed with six Calgiswabs (Colab Laboratories, Inc., Chicago Heights, Ill.), one for each of six different areas, moistened with $1 \%$ sodium citrate solution. The Calgiswabs were placed in $4 \mathrm{ml}$ of $1 \%$ sodium citrate and the calcium Alginate wool (8) was agitated until dissolved. Samples of $0.1 \mathrm{ml}$ were plated in triplicate on corn steep-agar plates (1). (ii) The beard was stroked for 2 min with a modified Millipore filter holder (Millipore Corp., Bedford, Mass.) containing a membrane filter connected to the laboratory vacuum. To obtain colonial growth, the membrane was aseptically transferred, collecting surface up, to a corn steep-agar plate. (iii) Six agar impressions were made on each beard with Rodac (Falcon Plastics Division, B-D Laboratories, Inc., Los Angeles, Calif.) plates containing corn steep agar (20). (iv) Finally, $250 \mathrm{ml}$ of sterile physiological saline containing $0.1 \%$ Naccanol wetting agent was used to rinse each beard, and the wash water was collected in a sterile emesis basin. The collected fluid was passed through a membrane filter and the filter was placed on a corn steep-agar plate. (v) $S$. marcescens-contaminated beards were combed for $1 \mathrm{~min}$ with a sterile aluminum comb fitted with nonabsorbent cotton between the tines. After combing, the cotton was removed aseptically, transferred to a sterile safety blender bowl containing 100 $\mathrm{ml}$ of sterile Nutrient Broth, and mixed for $5 \mathrm{~min}$ (15). Five 0.1-ml samples per beard were plated on corn steep-agar plates. The five techniques used for bacterial recovery are shown in Fig. 2.

For comparison, the experiment was repeated without beard washing.

As a terminal experiment, the beards were sheared and culture recovery methods were employed. Four bearded zones were designated: right temple, right chin, left temple, and left chin. The right side of each beard was sprayed with $0.5 \mathrm{ml}$ of $S$. marcescens and allowed to dry for $30 \mathrm{~min}$. Two men washed their beards and two did not. The right chin and the right temple zones were separately sheared with a hand scissors, and the hair from each zone was collected and separately blended for $2 \mathrm{~min}$ in a safety blender (15) containing $100 \mathrm{ml}$ of sterile Nutrient Broth. Each of 10 replicate $0.1-\mathrm{ml}$ samples of broth from each 


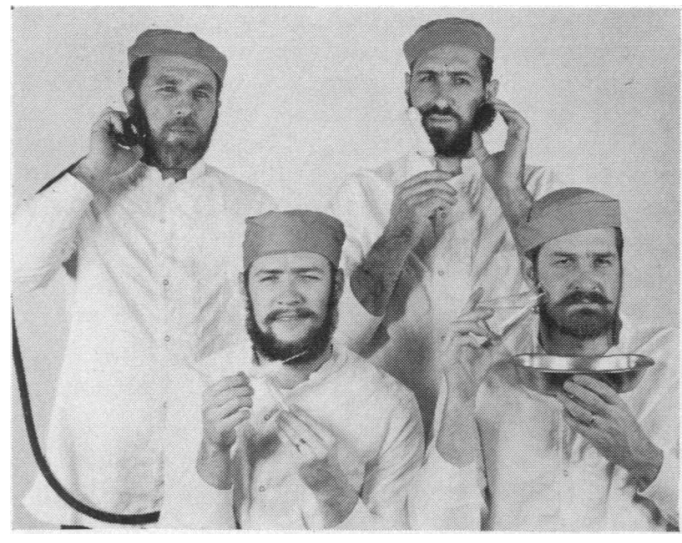

FIG. 2. Techniques for recovering microorganisms from beards. Top row: (left) modified Millipore filter holder; (right) aluminum comb fitted with nonabsorbent cotton, Rodac plate. Bottom row: (left) Calgiswab; (right) physiological saline rinse.

zone was plated on corn steep-agar. The total number of colonies from the 10 plates multiplied by 100 was taken as the number of bacteria recovered from each man's half chin or left or right temple. After the whole face, half bearded,and half stubble, had been soaped, washed, dried, rinsed with $70 \%$ ethyl alcohol, and air-dried, the process was repeated on the remaining left-side beard, with the use of $B$. subtilis var. niger.

Bacterial experiments with clean-shaven men. Five clean-shaven volunteers tested the persistence of $S$. marcescens and $B$. subtilis on the facial skin. The methods of spraying and sampling were the same as those for the bearded men, except that the combing method (5) was not used. In all tests, there was an interval of 30 min between the bacterial spraying and sampling.

Viral experiments with a bearded mannequin. To determine whether disease could be transmitted from a contaminated beard to a suitable host by intimate contact, NDV of chickens was selected as a test agent.

The chickens (parent stock: female White Leghorn; male White Rock or New Hampshire) were NDVfree, as shown by negative hemagglutination-inhibition (HI) activity ( $\beta$ procedure: constant virus, decreasing serum) tested prior to use (5), and by clinical appearance.

With both the washed and unwashed beards, three tests were run with a virus preparation having a titer of $10^{9.7}$ embryo $50 \%$ lethal doses per $\mathrm{ml}\left(\right.$ ELD $\left._{50} / \mathrm{ml}\right)$ as calculated by the Reed-Muench method (9). Another three tests were run with a virus preparation that titered $10^{4.7}$.

A mannequin fitted with a sterilized natural hair beard (Joseph Aquiar Co., Piscataway, N.J.) was placed in a specially equipped plastic exposure chamber within a ventilated gas-tight modular cabinet system (7). NDV (GB strain) was prepared by harvesting allantoic fluid from previously inoculated White Leghorn eggs. A 1-ml amount was sprayed on the beard with a small Chicago atomizer. After drying in the exposure chamber for $\mathbf{3 0} \mathrm{min}$, the beard was either washed or not washed, depending on the experiment. To test the unwashed beard, the bearded mannequin was passed into a separate contact-exposure section of the gas-tight cabinet. To test the washed beard, it was removed from the exposure chamber and washed in a separate cabinet with water at $40 \mathrm{C}$ and soap containing $2 \%$ hexachlorophene. It was toweled and then replaced in the contact-exposure section. The mannequin was rinsed separately with $70 \%$ ethyl alcohol and dried, and then was transferred to the contact-exposure section for reuse with the washed beard.

Each of three 6-week-old chickens was held with its head alternately nestled in the beard and stroked across one-third of the beard (one chicken on each side and one on the chin) for 5 min (Fig. 3). After this contact exposure, the chickens were housed individually in ultraviolet-irradiated (14) ventilated cages (13) in another section of the gas-tight cabinet system. Four control chickens also were placed within the cabinet system; none became infected. To minimize potential transfer of disease by the animal caretaker, a sealed automatic watering device was fabricated for the cages, and enough feed was placed in each cage to last for the duration of the experiment.

Four days after exposure to the contaminated beard, the chickens were sacrificed and attempts were made to recover virus from lung and spleen tissue. Samples (1 g) of spleen and lung tissues from each chicken were ground together in a Ten Broeck mill with $9 \mathrm{ml}$ of sterile Tryptose Broth containing $5,000 \mu \mathrm{g}$ of streptomycin per $\mathrm{ml}$ and 10,000 units of penicillin (19) per ml. After centrifugation of the broth at $900 \times g$ for $10 \mathrm{~min}$, each of ten 10-day-old embryonated eggs per bird was inoculated in the allantoic cavity with 0.2 $\mathrm{ml}$ of the broth supernatant fluid. The eggs were incu-

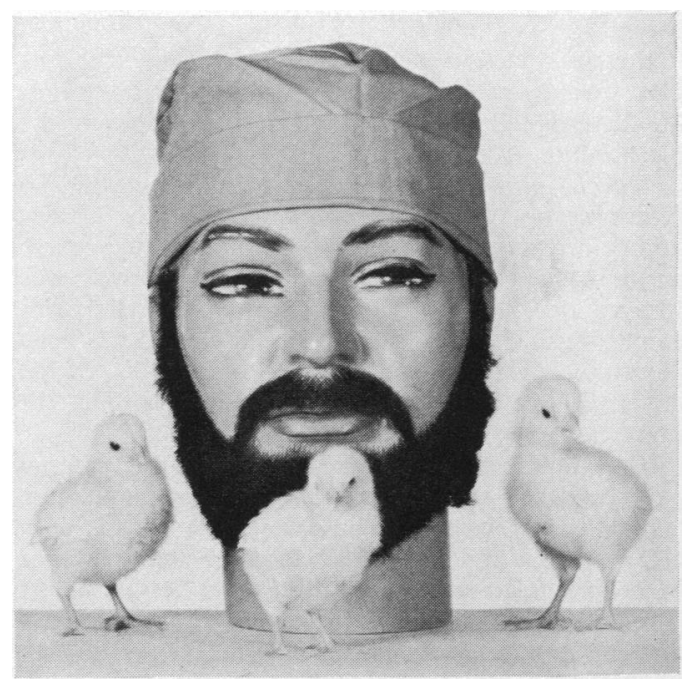

FIG. 3. Chickens exposed to natural hair beard on mannequin. 
bated at 37 to $38 \mathrm{C}$ at a relative humidity of 40 to $50 \%$.

All embryos that died within two to six days were refrigerated overnight, the allantoic fluid was harvested, and a one-tube hemagglutination (HA) test was run (5). All allantoic fluids with a positive HA test were pooled for each bird (maximum, 10 eggs). From this pooled allantoic fluid, complete HA tests were run; HI tests were also run with antiserum. Only after HI activity was obtained was the chicken considered positive for contact transmission of the virus from the washed or unwashed beard.

The experiment was repeated, and attempts were made to recover virus from the trachea and the brain of exposed chickens. One day after exposure to the contaminated beard, each separately caged chicken was passed into a special polyvinyl ventilated cabinet. Then each chicken was removed from its cage, and a Tryptose Broth-moistened Swube (Falcon Plastics Division, B-D Laboratories, Inc., Los Angeles, Calif.) was used to swab the larynx and upper trachea for recovery of NDV. The Swube was immersed in $2 \mathrm{ml}$ of Tryptose Broth containing penicillin and streptomycin and broken apart by vibrating the test tube on a mechanical vibrator. Then $0.1 \mathrm{ml}$ of the broth was injected into the allantoic cavity of 10-day-old embryonated eggs, 10 eggs per bird. Egg handling, incubation, and HA and HI tests were done as described previously. Throat swabs were taken from each bird at 24, 48, and $72 \mathrm{hr}$ after exposure. Birds also were examined for typical symptoms of NDV infection during the holding time. The same titers of virus were used as before.

If chickens from this group died in less than 7 days, the lungs and spleen were ground in Tryptose Broth; if death occurred between the 7th and 14th day after exposure, $1 \mathrm{~g}$ of brain tissue was ground in Tryptose Broth containing antibiotics. Eggs were inoculated with the supernatant fluid in the same manner as before.

Fourteen days after exposure, the surviving chickens were exsanguinated, and the NDV HI antibody titer was determined for each blood serum sample by the $\beta$ procedure.

Toxicity experiments with a bearded mannequin. To determine whether disease could be caused by inhalation or ingestion of toxin from a contaminated beard, partially purified $C$. botulinum type $A$ toxin was sprayed on the beard, and contact was tested with guinea pigs. The guinea pig respiratory $\mathbf{L D}_{50}$ has been reported as 141 mouse intraperitoneal $50 \%$ lethal doses (MIPLD 50 ), and the guinea pig oral $\mathbf{L D}_{50}$, as 717 MIPLD $_{50}$ (4).

The same test procedures for spraying the material on the beard, washing, handling of the mannequin, animal exposure, and caging were followed as with NDV, except that unventilated cages that had not been ultraviolet-irradiated were used to house the test animals. The guinea pigs, Hartley strain, weighed between 250 and $300 \mathrm{~g}$ each.

The beard was sprayed with $1 \mathrm{ml}$ of partially purified $C$. botulinum type A toxin containing $8 \times 10^{5}$ or $8 \times 10^{4}$ MIPLD $_{50} / \mathrm{ml}(18,23)$. Death within 10 days after exposure was used as the end point to determine toxin transmission from the beard via aerosol or oral contact, or both. Sixty guinea pigs were used to make five tests involving three guinea pigs in each test, for each of the two concentrations of toxin that was separately sprayed on the washed beard and on the unwashed beard. During each test, the nose and mouth of each of three guinea pigs were nestled and stroked across one-third of the beard for $5 \mathrm{~min}$.

\section{RESULTS}

Recovery of bacteria from bearded men. The recovery of test bacteria from bearded men with washed, unwashed, and sheared beards is summarized in Table 1 . In unwashed beards when 30 min elapsed between spraying of the beard and sampling, more $S$. marcescens than $B$. subtilis was recovered. Statistically, the difference between the means is significant at about the $10 \%$ level. After $6 \mathrm{hr}$ of drying, this situation was reversed in accordance with a reported rate of decay in viability of $9.64 \%$ per min for $S$. marcescens (10) and a rate of $0.93 \%$ per min for $B$. subtilis spores (10). Statistically, the difference between the means is significant at about the $20 \%$ level.

In the unsheared beards that were washed after the bacterial spray had dried for $30 \mathrm{~min}$, so few bacteria were recovered that statistically there is no significant difference between the means, the two species, and the two washing techniques with the limited number of tests conducted.

Shearing the beard and treating the hair in Nutrient Broth in a blender increased the number of bacteria recovered from unwashed beards. The importance of this is that the other methods of sampling underestimated the potential infectious dose that a family member might obtain by intimate contact with the unwashed beards. It is evident that family infection is possible if the beard is contaminated by the etiological agents of such diseases as $\mathbf{Q}$ fever, tularemia, Venezuelan equine encephalomyelitis, and West Nile fever, for which the inhaled human infectious dose is about 10 microorganisms or animal infective units (22).

Recovery of bacteria from clean-shaven men. Recovery of test bacteria from both the washed and unwashed clean-shaven faces is summarized in Table 2. Differences between bacterial recovery from the washed attached beard and recovery from the washed face do not seem significant. At $30 \mathrm{~min}$ after spraying, more bacteria were recovered from the unwashed face than from the unwashed attached beard, but $30 \mathrm{~min}$ after spraying more bacteria were recovered from the unwashed hair treated in the blender than from the unwashed face. Data to support this latter observation were obtained by adding the figures for the half-chin and one-temple zone of 
TABLE 1. Recovery of bacteria from beards

\begin{tabular}{|c|c|c|c|c|c|c|c|c|}
\hline \multirow{3}{*}{ Condition } & \multicolumn{8}{|c|}{ Avg bacterial colony count per test } \\
\hline & \multicolumn{4}{|c|}{ Serratia marcescens } & \multicolumn{4}{|c|}{ Bacillus subtilis } \\
\hline & $\mathrm{JFM}^{a}$ & JM & TM & MB & JFM & JM & TM & MB \\
\hline Unwashed beards & & & & & & & & \\
\hline $\begin{array}{l}30 \mathrm{~min} \text { between bacterial spraying } \\
\text { and sampling }\end{array}$ & $\mathrm{ND}^{c}$ & 488 & 449 & 858 & ND & 223 & 191 & 320 \\
\hline $\begin{array}{l}\text { and sampling........... } \\
30 \mathrm{~min} \text { between spraying and }\end{array}$ & ND & $423^{d}$ & $257^{d}$ & $152^{d}$ & ND & $1,151^{e}$ & $567^{e}$ & $467 e$ \\
\hline 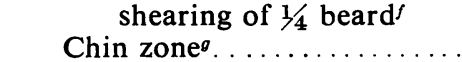 & ND & 2,303 & ND & 1,217 & ND & 750 & ND & 1,054 \\
\hline Temple zone ${ }^{g}$ & ND & 1,845 & ND & 1,071 & ND & 527 & ND & 1,244 \\
\hline $\begin{array}{l}\text { Washed beards } \\
30 \text { min between bacterial spraying } \\
\text { and sampling }\end{array}$ & & & & & & & & \\
\hline Shower stream wash & 26 & 3 & ND & ND & 3 & 3 & ND & ND \\
\hline Tests positive/tests done. & $3 / 10$ & $3 / 10$ & ND & ND & $6 / 10$ & $3 / 10$ & ND & ND \\
\hline Splashing wash. & ND & ND & 28 & 188 & ND & ND & 5 & 18 \\
\hline Tests positive/tests done & ND & ND & $7 / 10$ & $10 / 10$ & ND & ND & $6 / 10$ & $9 / 10$ \\
\hline $\begin{array}{l}\text { Sheared } 1 / 4 \text { beard }^{f} \\
\text { Shower stream wash }\end{array}$ & & & & & & & & \\
\hline Chin zone ${ }^{\theta} \ldots \ldots$ & 0 & ND & ND & ND & 1,000 & ND & ND & ND \\
\hline Temple zone ${ }^{g}$ & 0 & ND & ND & ND & 0 & ND & ND & ND \\
\hline Splashing wash & & & & & & & & \\
\hline Chin zone ${ }^{o}$. & ND & ND & 0 & ND & ND & ND & $(1,755)^{h}$ & ND \\
\hline Temple zone ${ }^{a}$ & ND & ND & $\mathbf{0}$ & ND & ND & ND & 100 & ND \\
\hline
\end{tabular}

${ }^{a}$ Volunteers.

${ }^{b}$ Four replicate tests per beard. Bacteria were recovered in all four tests.

c Not done.

${ }^{d}$ Two replicate tests per beard.

- One test per beard.

$f$ On one half of each beard, $5 \times 10^{4} \mathrm{~S}$. marcescens and $3 \times 10^{4} \mathrm{~B}$. subtilis were sprayed.

- One test per one half chin or temple. For each man, add chin and temple and multiply by 2 for approximate comparability with other figures.

${ }^{h}$ This sheared chin zone not washed before shearing.

each man and multiplying by two to get an estimate for all the bearded area; e.g., volunteers JM and MB would yield 8,296 and 4,576, respectively, for $S$. marcescens, and 2,554 and 4,596, respectively, for $B$. subtilis, compared with the facial recoveries of $5,074,1,289,807$, and 1,927 respectively. This suggests that bacteria hold more tenaciously to the beard than to the face. This tentative conclusion is strengthened by noticing that washing the face removes a larger number of bacteria than does washing the attached beard, e.g., respective reductions from (face) 5,074 to 125 , compared with (beard) 488 to $3 ; 469$ to 0 , compared with 449 to $28 ; 1,289$ to 0 , compared with 858 to $188 ; 807$ to 7 , compared with 223 to $3 ; 2,375$ to 77 , compared with 191 to 5 , and 1,927 to 20 , compared with 320 to 18 .

It seems that, given an equal amount of bac- terial contamination, soap and water removes more bacteria from the facial skin than from a beard.

Recovery of virus from bearded mannequin. Recovery of virus from lung and spleen is summarized in Table 3. The unpredictable effect of the many variables in this experiment is illustrated by the fact that, among nine chickens, two (no. 14 and 18) contracted disease by contact with the beard that was washed $30 \mathrm{~min}$ after it had been sprayed with the low-titered virus, but none of 9 chickens (no. 1 through 9) contracted disease from the high-titered virus. With the unwashed beard, the results were consistent in that none of the nine chickens (no. 46 to 54) was infected by the low-titered contamination and all of the 9 chickens (no. 37 to 45 ) were infected by the hightitered contamination. However, the results with 
TABLE 2. Recovery of bacteria from the faces of clean-shaven men

\begin{tabular}{|c|c|c|c|c|c|c|c|c|c|c|}
\hline \multirow{3}{*}{ Determination } & \multicolumn{10}{|c|}{ Avg bacterial colony count per test } \\
\hline & \multicolumn{5}{|c|}{ Serratia marcescens ${ }^{a}$} & \multicolumn{5}{|c|}{ Bacillus subtilis ${ }^{b}$} \\
\hline & $\mathrm{JM}^{c}$ & LT & CG & TM & MB & JM & LT & CG & TM & MB \\
\hline $\begin{array}{l}\text { Unwashed face. . . . . . } \\
\text { Tests positive/tests }\end{array}$ & 5,074 & 1,289 & 1,483 & 469 & 1,289 & 807 & 916 & 1,744 & 2,375 & 1,927 \\
\hline done. ......... & $2 / 2$ & $2 / 2$ & $2 / 2$ & $2 / 2$ & $2 / 2$ & $2 / 2$ & $2 / 2$ & $2 / 2$ & $2 / 2$ & $2 / 2$ \\
\hline $\begin{array}{l}\text { Washed face } \\
\text { Shower stream wash. } \\
\text { Tests positive/tests }\end{array}$ & 125 & $\mathbf{0}$ & $\mathbf{0}$ & ND & ND & 7 & 4 & 1 & ND & ND \\
\hline done. . & $1 / 2$ & $0 / 2$ & $0 / 2$ & ND & ND & $1 / 2$ & $2 / 2$ & $2 / 2$ & ND & ND \\
\hline $\begin{array}{l}\text { Splashing wash. .... } \\
\text { Tests positive/tes }\end{array}$ & ND & ND & ND & 0 & 0 & ND & ND & ND & 77 & 20 \\
\hline done. ............ & ND & ND & ND & $0 / 2$ & $0 / 2$ & ND & ND & ND & $2 / 2$ & $1 / 2$ \\
\hline
\end{tabular}

a Total bacteria sprayed on the face per test was $9 \times 10^{4}$.

${ }^{b}$ Total bacteria sprayed on the face per test was $7 \times 10^{4}$.

c Volunteers.

chickens 46 to 54 compared with chickens 14 and 18 re-emphasize the previously mentioned variability of results with chickens 14 and 18 .

Recovery of virus from the trachea and brain is summarized in Table 4 . Contact by 9 chickens with the beard that was washed 30 min after it had been sprayed with $1 \mathrm{ml}$ of the high-titered virus $\left(10^{9.7} \mathrm{ELD}_{50} / \mathrm{ml}\right)$ resulted in infection of four chickens, no. $20,23,24,25$. None of nine was infected by the low-titered virus in either washed or unwashed beard. All nine chickens (no. 55 through 63) were infected by contact with the unwashed beard sprayed with $1 \mathrm{ml}$ of the hightitered virus.

TaBle 3. Recovery of Newcastle disease virus from lung and spleen of chickens in contact with the virus-contaminated bearded mannequin

\begin{tabular}{|c|c|c|}
\hline Beard treatment & Chicken no. & $\begin{array}{l}\text { Hemag- } \\
\text { glutination- } \\
\text { inhibition } \\
\text { titer units }\end{array}$ \\
\hline $\begin{array}{l}\text { Washed } 30 \text { min after } \\
\text { spraying with } \\
10^{4.6} \text { ELD } 50 \\
10^{4.5} \text { ELD }_{50} \\
10^{9.7} \text { ELD }_{50} \\
\text { Unwashed, sprayed } \\
\text { with } \\
10^{4.5} \text { ELD }_{50} \\
10^{9.7} \text { ELD }_{50} \\
10^{9.7} \text { ELD }_{50} \\
10^{9.7} \text { ELD }_{50}\end{array}$ & $\begin{array}{l}14,18 \\
10,11,12,13 \\
15,16,17 \\
1-9 \\
\\
46-54 \\
38,41,44 \\
39,40,43 \\
37,42,45\end{array}$ & $\begin{array}{r}0 \\
800 \\
1,600 \\
3,200\end{array}$ \\
\hline
\end{tabular}

a Reciprocal of dilution.
Recovery of bacterial toxin from bearded mannequin. The results showed no differences between the two test concentrations of $8 \times 10^{5}$ and $8 \times 10^{4}$ MIPLD $_{50} / \mathrm{ml}$ of toxin, nor between the washed and unwashed beard. One guinea pig of the 15 exposed in each of the four test groups died within 10 days after exposure.

TABLE 4. Recovery of Newcastle disease virus from trachea and brain of chickens in contact with the virus-contaminated bearded mannequin

\begin{tabular}{|c|c|c|c|c|c|}
\hline \multirow[b]{2}{*}{ Beard treatment } & \multirow[b]{2}{*}{$\begin{array}{l}\text { Chicken } \\
\text { no. }\end{array}$} & \multicolumn{4}{|c|}{$\begin{array}{l}\text { Hemagglutination- inhibition } \\
\text { titer units }{ }^{a}\end{array}$} \\
\hline & & $\begin{array}{l}\text { Tracheal } \\
\text { swab 72 } \\
\text { hr after } \\
\text { exposure }\end{array}$ & $\begin{array}{l}\text { Brain } \\
\text { sample }\end{array}$ & $\begin{array}{c}\text { Lung } \\
\text { or } \\
\text { spleen }\end{array}$ & $\begin{array}{l}\text { Blood } \\
\text { serum }\end{array}$ \\
\hline 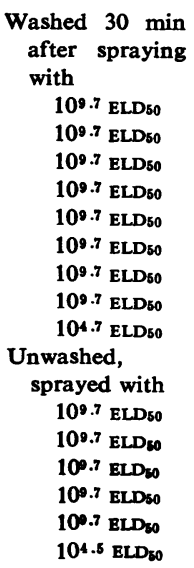 & $\begin{array}{l}19 \\
20 \\
21,22 \\
23 \\
24 \\
25 \\
26 \\
27 \\
64-72 \\
\\
55 \\
58,59,63 \\
61 \\
56,57,60 \\
62 \\
28-36\end{array}$ & $\begin{array}{r}800 \\
800 \\
1,270 \\
1,600 \\
3,200 \\
0\end{array}$ & $\begin{array}{r}1,600 \\
800 \\
800 \\
800 \\
800\end{array}$ & $\begin{array}{l}800 \\
800\end{array}$ & $\begin{array}{r}0 \\
100 \\
0\end{array}$ \\
\hline
\end{tabular}

${ }^{a}$ Reciprocal of dilution. 


\section{Discussion}

$S$. marcescens and spores of $B$. subtilis var. niger were recovered from washed and unwashed beards, from hair shorn before and after, washing, and from washed and unwashed clean-shaven facial skin, when microbiological cultural recovery techniques were started $30 \mathrm{~min}$ after the bacteria had been sprayed on the areas. Both species of bacteria were recovered from unwashed beards 6 $\mathrm{hr}$ after the bacteria had been sprayed on the beards.

More bacteria could be recovered from cleanshaven facial skin than from the attached beard, and more bacteria were washed off the cleanshaven skin during showering than were washed off the attached beards. Retention of bacteria by the beard was demonstrated by the finding that more bacteria could be recovered from the unwashed beard hair by shearing it off and mixing it in a blender with broth than by recovery techniques. used on the attached unwashed beard. This differential retention was not clearly demonstrable in the case of washed beards.

Application of these findings to laboratory situations requires an attempt at quantitation. To obtain culture recovery of bacteria from the washed beard, it was necessary to spray the beard with $10^{5} \mathrm{~S}$. marcescens organisms or $10^{4} \mathrm{~B}$. subtilis spores. Fewer would be required for the unwashed beard. Review of the number of $S$. marcescens organisms recovered by air sampling during simulation of various routine microbiological techniques (16), and recovered immediately after common laboratory accidents, when compared with the dose needed to infect man, shows that (i) most techniques, even when repeated many times, would not contaminate the beard to the $10^{4}$ level, and (ii) it is unlikely that the beard would be contaminated with $10^{4}$ or $10^{5}$ bacteria or viral units without concurrent inhalation of enough organisms to cause illness.

Therefore, infection of family or friends outside the laboratory by an uninfected bearded man would occur only when the bearded man had a recognizable microbiological accident with a persistent highly infectious microorganism, or was engaged in a repetitious operation that aerosolized a significant number of organisms, and if he himself were protected by vaccination or immunity following clinical or subclinical disease.

A typical repetitious operation would be one on an open bench with Coxiella burnetii, such as grinding in a mortar, using a blender, decanting a supernatant fluid, or removing a cotton plug from a shaken culture. In this situation, we could conclude that (i) a bearded man is a more dangerous carrier than a clean-shaven man because the beard is more resistant to cleansing and (ii) one working with infectious microorganisms should wash his beard or clean-shaven face before going home.

Results of studies with the bearded mannequin, sprayed with NDV and tested with chickens, or sprayed with type A botulinum toxin and tested with guinea pigs, were unexpected because of the large amount of test agent that had to be sprayed on the beard before contact with the washed beard would cause disease in the chickens or guinea pigs. However, the potential for human infection is illustrated by the two chickens that contracted Newcastle disease after contact with one-third of a washed beard sprayed 30 min before with $10^{4.5} \mathrm{ELD}_{50}\left(31,620 \mathrm{ELD}_{50}\right)$; in other words, each chicken was in contact with a bearded area sprayed with only 10,540 ELD $_{50}$ before washing. More impressive are the results with the one guinea pig that obtained a lethal dose of botulinum toxin by contact with a washed beard, onethird of which was sprayed 30 min before with $2.66 \times 10^{4}$ MIPLD $_{50}$. This is equivalent to an estimated 266 human lethal doses. These contaminations are within the range of possible accidental contamination of a beard by a microbial suspension.

\section{ACKNOWLEDGMENTS}

The guidance of A. G. Wedum is appreciated. The authors are indebted to James F. Martin and James E. Main for their bearded participation and to Martin and Gayle $T$. Long for their laboratory assistance. E. J. Schantz advised us concerning the $C$. botulinum toxin and R. L. Schricker, W. A. Chappell, and C. Beard advised us concerning NDV.

\section{Literature Cited}

1. BARBerto, M. S. 1966. Emergency disinfection of operating room and patient ward with betapropiolactone. Hospitals 40:100-106.

2. BEEMAN, E. A. 1950 . Q fever: an epidemiological note. Public Health Rept. U.S. 65:88-92.

3. Best, R. R., J. D. CoE, G. B. MCMurtrey, AND MARY Jo HenN. 1950. Effectiveness of soaps containing hexachlorophene for the surgical scrub, special reference to bar soap. Arch. Surg. $61: 869$.

4. Cardella, M. A. 1964. Botulinum toxoids. Proc. Symp. Botulinum, U.S. Public Health Serv. Publ. 999-FP-1, p. 113-130.

5. Cunningham, C. H. 1964. A laboratory guide in virology. 5th ed., p. 80-87. Burgess Publishing Co., Minneapolis.

6. Ferris, D. H., and C. A. Brandly. 1964. Comparative $\mathbf{Q}$ fever investigations. Am. J. Public Health 54:1282-1288.

7. Gremillion, G. G. 1960. The use of bacteriatight cabinets in the infectious disease laboratory. Proc. Symp. Gnotobiotic Technology, 
p. 171-182. Univ. of Notre Dame Press, Notre Dame, Ind.

8. Higgins, M. A. 1950. A comparison of the recovery rate of organisms from cotton-wool, and calcium alginate wool swabs. Monthly Bull. Ministry Health Public Health Lab. Serv. 19: 50-51.

9. LeNNette, E. H., AND N. J. SChmidT. 1964. Diagnostic procedures for viral and rickettsial diseases, 3rd ed., p. 47-48. American Public Health Association, Inc., New York.

10. Miller, W. S., R. A. SCherff, C. R. Piepoli, AND L. S. IDorne. 1961. Physical tracers for bacterial aerosols. Appl. Microbiol. 9:248-251.

11. Oliphant, J. W., D. A. Gordon, A. Meis, and R. R. PARKER. 1949. Q fever in laundry workers, presumably transmitted from contaminated clothing. Am. J. Hyg. 49:76-82.

12. Phillips, G. B. 1965. Microbiological hazards in the laboratory. I. Control. J. Chem. Educ. 42A: 43-48.

13. Phillips, G. B. 1965. Microbiological hazards in the laboratory. II. Prevention. J. Chem. Educ. 42A:117-130.

14. Phillips, G. B., M. Reitman, C. L. Mullican, AND G. D. GARDNER, JR. 1957. Applications of germicidal ultraviolet in infectious disease laboratories. III. The use of ultraviolet barriers on animal cage racks. Proc. Animal Care Panel 7:235-244.

15. Reitman, M., M. A. Frank, SR., R. L. Alg, AND W. S. Miller. 1954. Modifications of the highspeed safety blender. Appl. Microbiol. 2:173.

16. Reitman, M., AND A. G. Wedum. 1956. Microbiological safety. Public Health Rept. U. S. $71: 659-665$.

17. ROSEbuRY, T. 1947. Experimental air-borne infection. The Williams \& Wilkins Co., Baltimore.

18. Schantz, E. J., AND L. Spero, 1957. The reaction of botulinum toxin type A with ketene. J. Am. Chem. Soc. 79:1623-1625.

19. Sinha, S. K., R. P. Hanson, and C. A. Brandly. 1952. Comparison of the tropisms of six strains of Newcastle disease virus in chickens following aerosol infection. J. Infect. Diseases 91:276282.

20. UlRiCh, J. A. 1964. Technic of skin sampling for microbial contaminants. Health Lab Sci. 1: 133-136.

21. WEBB, S. J. 1959. Factors affecting the viability of air-borne bacteria. I. Bacteria aerosolized from distilled water. Can. J. Microbiol. 5:649-669.

22. Wedum, A. G. 1964. Laboratory safety in research with infectious aerosols. Public Health Rept. U. S. 79:619-633.

23. Weiss, E. S. 1948. An abridged table of probits for use in the graphic solution of the dosage effect curve. Am. J. Public Health 38:22-24. 